\title{
WHOSE SIDE ARE YOU ON? Structure and rhetoric in Christ's parable of the sheep and the goats (Matthew 25:31-46), with special reference to Bible translation
}

\author{
Ernst Wendland \\ University of Stellenbosch
}

\begin{abstract}
This well-known eschatological passage from Matthew is examined from two complementary discourse perspectives. First, the elaborate structural organization of the text is presented in terms of its salient compositional parallels and main points of internal divergence within the principal pattern of development. Secondly, I will summarize some of the chief aspects of rhetorical significance that are manifested by the masterful blending of form and content in relation to the wider discourse context of this parabolic pericope. In conclusion, I will offer a few suggestions as to the practical relevance of this sort of analysis for translators who wish to convey a greater measure of its considerable communicative impact and persuasive appeal for a contemporary audience in another language and culture. The aim and approach of this short paper has been both stimulated and informed by similar studies that have appeared among the many scholarly writings of Bernard Combrink, to whom I gratefully dedicate the present effort.
\end{abstract}

\section{Introduction: What do text structure and rhetoric have to do with Bible translation?}

Whose side are you on? This crucial theological question that arises from the passage under consideration poses a challenge that Bible translators too must answer. What sort of a rendition will they prepare - one that is more, or less, formally concordant/colloquial in nature, or one that is more, or less, semantically intelligible for the majority of receptors? In other words, is the primary task for the project at hand to transfer the forms of the original text into a given target language (TL) - or to convey its basic content and communicative intention(s) in readily perceptible and comprehensible TL terms? Translators cannot really do both, and therefore a fundamental choice concerning compositional strategy and style has to be made, one way or the other.

Our response to this crucial query depends very much on the type of translation that is desired in order to best serve the consumer community concerned (cf. Wilt 2002: ch.1). In this paper I recommend the consideration, as one possible option, of a more dynamic, idiomatic style of rendering which is intended to cater for a particular audience-that is, a literary functional equivalent version prepared specifically for the "life-now" generation of pre-middle-agers living in Chichewa-speaking south-central Africa. The dramatic scenario portrayed at the end of Matthew 25 presents life-and-death issues in a very traditional, down-to-earth, and hence powerful way. It is a therefore a text that would seem to call for a suitably dynamic method of interlingual re-presentation, especially in an age and for a society where death is an ever-present reality of everyday existence.

It is not possible within the confines of this short study to present a detailed sociological, exegetical, or intertextual analysis of this passage, which is so rich in both 
denotative and connotative meaning. Instead, I will limit my attention to a survey of some of its larger formative dimensions, which are often overlooked due to the familiarity of the text's surface content. I will thus focus on the underlying discourse structure in order to reveal what it can tell us about certain important aspects of the theological and ethical significance of this pericope. The aim is further to suggest how such knowledge can be of benefit for Bible translators today who seek to communicate these same diverse elements of meaning in an acceptable and relevant manner within the context of a new linguistic and cultural setting.

An increasing number of scholarly studies are drawing attention to the importance of a thorough consideration of macro-style, structure, and rhetoric in the discourse analysis of biblical texts. Our main problem nowadays is not, like in the past, to find such information, but rather to know what to do with it, specifically in terms of translating the Scriptures for a modern reading (listening, viewing) constituency. Is such implicit compositional "meaning" important enough to attempt to reproduce in translation? If so, what is the best way to do this-if the task is possible to accomplish at all.

The use of paragraph and sectional breaks (with or without accompanying headings or titles) is now standard procedure in the production of modern Bibles. Most people have become accustomed to using these features as an indispensable guide to the broader organization of the Scriptures, whether an individual section or a complete book. A larger number of expository footnotes that deal with text-related issues and literary qualities is also being added many current versions. But there is a limit to what one can explain or describe by such means. Moreover, how is one to handle the actual discourse design of the original? This refers to the artful manner in which the text has been arranged in terms of parallel, reversed, layered, and other patterns involving key formal and semantic similarities, contrasts, or other relationships (e.g., cause-effect, temporal or spatial sequence, assertion-rejoinder, appeal-motivation, and so forth). I will give special attention to this particular aspect of Matthew's heavenly judgment scene, recognizing that it is just one vital part of the total text communication process. How has this pericope been structured in terms of its larger format, both internally as well as externally (i.e., in terms of the co-text), and what is the rhetorical significance of such patterning?

\section{The structure of rhetoric}

A great deal of the literary excellence and rhetorical power of Christ's apocalyptic narrative drama is exemplified in the carefully chosen manner in which this climactic text has been crafted. Even a cursory examination reveals the dominant step-for-step contrastive pattern that is manifested within an overall structure of parallel paneling. A closer look is necessary however, to uncover some of the finer features of the expert textual tectonics that characterize this discourse. A rhetorically motivated construction of such excellence can be fully appreciated only in the original language and through the use of a special typographical format that is intended to better display the balance and symmetry of the whole as it flows in a progressive thematic and persuasive build-up from beginning to end. It clearly reflects in its very compositional form the consequential ethical choice that the Lord foregrounds in order to challenge the faith-life of every audience that hears the unequivocal hortatory appeal of this passage.

The cumulative, complementary syntagmatic and paradigmatic discourse development of Matthew 25:31-46 is set out below in a way that is intended to call attention to the chief textual parallels of the Greek text (cf. Maartens 1982, Addendum:50-52). The corresponding constituents of a terraced pair of largely contrastive discourse panels $(\mathrm{X}, \mathrm{Y})$ are 
highlighted both by the varied levels of indentation and also by the sequence of capital letters on the right hand margin, each of which is attached to a specific paragraph of the unfolding narrative. Some of the key variations (additions, differences) in vocabulary are manifested by underlining.

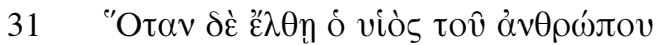

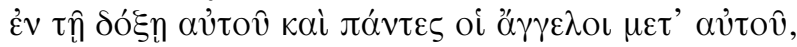

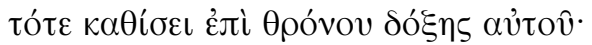

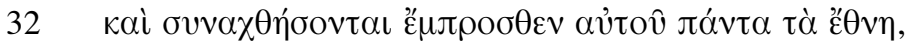

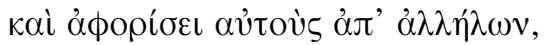

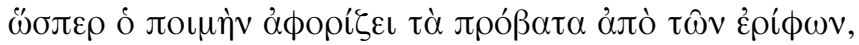

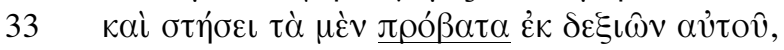

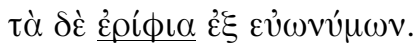

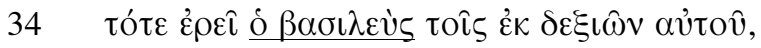

B

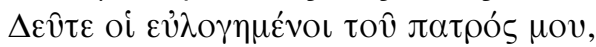

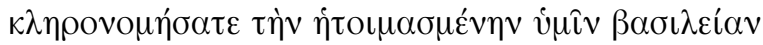

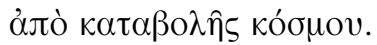

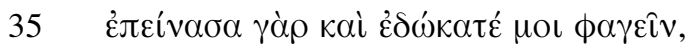

Ca

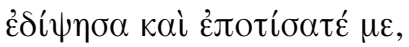

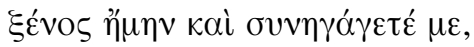

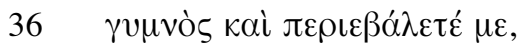

c

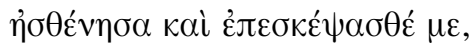

d

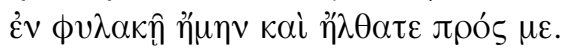

e

f

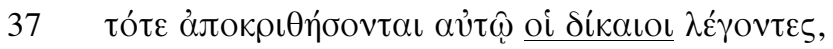

D

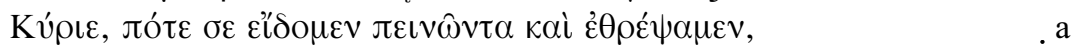

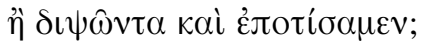

$\mathrm{b}$

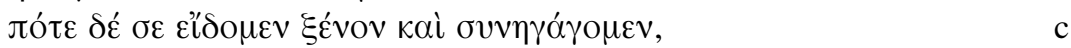

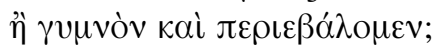

d

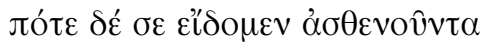

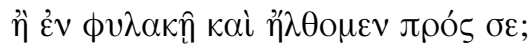

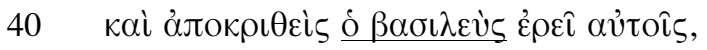

$\mathbf{E}$

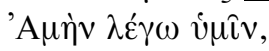

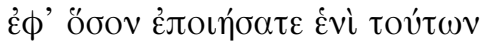

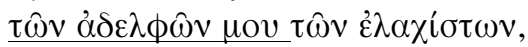

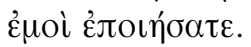

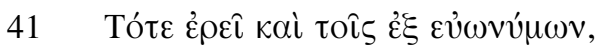

B'

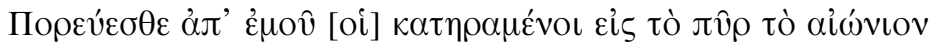

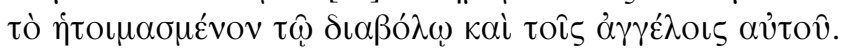

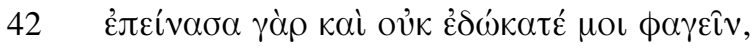

C'a'

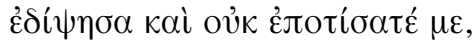

b'

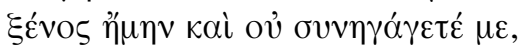

c'

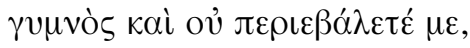

d' 


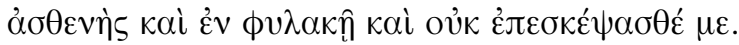

e'-f'

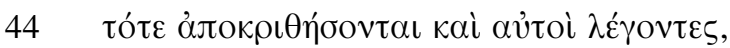

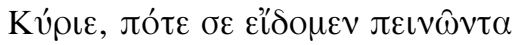

ทे $\delta \iota \psi \hat{\omega} \nu \tau \alpha$

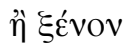

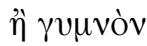

ทे $\alpha \sigma \theta \varepsilon v \hat{\eta}$

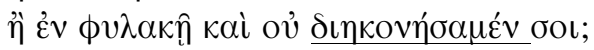

D'

a'

b'

c'

d'

e'

f'

$\mathbf{E}^{\prime}$

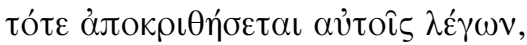

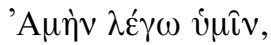

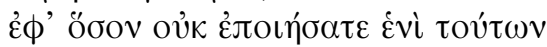

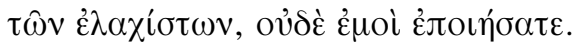

46

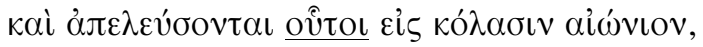

$\mathbf{A}^{\prime}$

As shown above, each half, or "panel", of the discourse consists of five discrete paragraph units. The last segment (A') corresponds both structurally and functionally to complement the first (A) in forming an inclusio that highlights the external borders of the entire pericope. This device is reinforced by the chiastic placement of the focal participants in verses 33 and 46, i.e., sheep : goats :: "these" [condemned] : righteous. The contrastive internal segments match each other sequentially according to the following linear pattern: $X$ : A-B-C-D-E // $Y:$ B'-C'-D'-E'-A'. The respective C/C' and D/D' units also correspond contrastively by virtue of two ordered sequences of repeated events (a-f and a'f'). The compelling rhetorical significance of such a patently contrived arrangement of Christ's eschatological prediction is discussed below, after a preliminary consideration of its literary genre.

\section{Genre in relation to discourse structure and rhetoric}

Any credible analysis of the structure and rhetoric of a given literary work must begin with the notion of genre, for generic conventions are normally reflected both in the macro- as well as in the micro-stylistic features of the text, whether oral or written. It is not possible here to fully enter the debate concerning the specific genre of Matthew 25:31-46, or indeed that of the "gospel" as a whole. For my purpose, it is sufficient to build upon the foundation that was so well laid by Bernard Combrink in this regard $(1982,1983)$, which in fact does not differ much in its broad contours from more recent proposals (e.g., McKnight 1992:531; Boring 1995:117).

[I]n whatever manner the genre of Matthew can be defined in more detail, it can be taken to be a narrative as it meets the two basic characteristics: "the presence of a story and a story-teller" (citing R Scholes \& R Kellogg). And it is no simple narrative, but it is a "narrative with plot, which is less often chronological and more often arranged according to a preconceived artistic principle determined by the nature of the plot..." [involving a dramatic movement from conflict through climax to resolution] (citing $\mathrm{CH}$ Holman), (Combrink 1983:66; I have added the comment in brackets). 
To the general classification of dramatic narrative, we might qualify the gospel genre in two further respects, both of which pertain to Matthew's last judgment pericope. First, a gospel, oral and/or written, is a biographical narrative, that is, it focuses on selected, significant aspects of the personal life history and character of a human being, Jesus of Nazareth, the Son of Man, who was born, lived, and died in the world region of Palestine. There may also be an apologetic edge to the account since certain portions are clearly "designed to dispel false images of Jesus" (Bailey \& van der Broek 1992:93). Second, and more specifically, a gospel also relates the account of a divine being, Christ the Son of God, who was incarnated to feature as the central character of the Lord's salvation story as this transpired on the stage of human history according to a divinely willed and worked plan (or "plot"). So completely does a gospel foreground the nature, life, and mission of Jesus the Christ that the theme of any one of these four distinct narratives may be described as being pervasively christological in essence, which normally includes an implicit or nascent element of early ecclesiology as well (Boring 1995:109).

Several further specifications need to be made with regard to the complex generic nature of the passage found in 25:31-46. Does it present itself as an historical or a parabolic text? Some (e.g., Boring 1995:445) classify the discourse as dramatic history-as nonfictional writing that incorporates certain apocalyptic features which are set within an eschatological temporal setting at the royal advent of the divine Son of Man (25:31; cf. Dan. 7:13-14). Others point to the prominent comparative component, one that begins with the metaphor of the sheep and the goats and runs throughout the text, as well as to the fact that it appears to function as a climax (the $7^{\text {th }}$ ) of Matthew's "previous parables of separation and comparison that are oriented to the final judgment $(7: 24-27 ; 13: 24-30[+]$ 36-43, 47-50; 24:45-51; 25:1-13, 14-30)" (Carter \& Heil 1998:208).

No matter how the text is classified in literary terms (being perhaps, like "gospel" itself, generically "mixed" in nature), it is clear that the point of Christ's discourse is not primarily informative-to reveal and explain the earth shaking events that will transpire at the end of time (what things will be like). Rather, it is distinctly imperative-intended to motivate appropriate, here-and-now ethical behavior within members of the Kingdom (what they should be like). Thus what we have here is not simply a descriptive narrative account intended to instruct or ingratiate the audience; instead, it is a vivid pastoral appeal that is calculated to encourage crucial attitudes and actions that befit all those "righteous [folk who will ultimately] enter into eternal life" $(25: 46)$. This identification of general communicative purpose leads us to a consideration of certain prominent rhetorical features that set the scene and animate the Lord's dramatic portrayal of his consequential postparousia judgment activity.

\section{On the rhetoric of structure}

Again, only an overview of this vital aspect of the judgment discourse can be presented. First, with respect to the larger structural unit of which 25:31-46 forms an integral part, as the text has been arranged in Matthew, we note the following points: Our pericope forms the final section of a tripartite, seven-sectioned A-B-A' ring composition. After an initial narrative aperture (24:3; see 26:1 for the closure), Christ begins his paraenetic instruction concerning "the end of the age" by describing some of the salient signs of "those days" (often a subtle blend of key events that will occur during the prophetic times of both the messianic and also the eschatological ages; 24:4-31 // A). This semi-narrative prediction suddenly breaks off ("So from the fig tree learn this parable...," 24:32), and the discourse shifts into a parabolic mode with a series of five hortatory texts that reinforce one another 
in stressing the need for preparing properly in view of a final day of decision $(24: 32-35,36$ 44, 45-51; 25:1-13, 14-30 // B).

The seemingly resumptive section A' $(25: 31-46)$ then begins, the seventh portion of the discourse as a whole. This appears to continue the eschatological account where A left off, namely, with the Son of Man coming from heaven in glory, accompanied by his angels and in the presence of all humanity (24:30-31 $\Rightarrow 25: 31-32)$. The contrastive judgment dialogue scene ends with the wicked being consigned to "eternal punishment", a theme that marks the ending of several of the preceding parables (e.g., 24:51, 25:30; i.e., structural epiphora). Thus the ambiguous generic character of the discourse (i.e., is it history and/or parable?) may be a deliberate rhetorical device intended to focus not so much on the individual details of the eschatological event but rather on the certainty of its actual occurrence one day. In any case, the text has clearly been constructed to produce a structural and rhetorical climax in this third unit, especially with its summary conclusion regarding the great separation between "the righteous" and the rest (25:46). Such a perspective is supported by a similar, ethically toned antithetical passage having a binary sequential arrangement that occurs at the end of the first major discourse of Christ in Matthew's gospel (the parable of the wise and foolish builders, 7:24-27).

By virtue of the naturally prominent narrative device of end stress, the burden of this private instruction to his disciples would seem to be the Lord's dramatic exhortation to put their professed faith into practice as a life-long habit through concrete acts of loving assistance on behalf of "the least of [the Lord's] brothers" (25:40, 45; cf. 22:34-40). That is where real "kingdom of heaven" work begins $(25: 1,14)$, and this is the personal evidence which Christ the king will testify for-or against-in the judgment. Thus "salvation" for the righteous is initiated in this earthly life, being manifested by their selfless deeds of "service" (25:44; cf. Wilson 1989:180). This implicit encouragement-or warning-as the case may be, though set within a particular historical setting, is like any parable timeless in its persuasive relevance and potential application to any individual or audience in attendance. It is interesting to observe that this deceptively simple account reflects aspects of all three of the so-called species of classical Greco-Roman rhetoric: While the surface of the text reveals certain judicial as well as epideictic concerns (i.e., seeking to influence the audience with regard to a right versus wrong legal standard and an honorable versus dishonorable value system), the real import of the message is deliberative in nature, that is, intended to convince listeners concerning the expediency of specified beneficial behavior in contrast to detrimental actions in view of a future day of public reckoning (Kennedy 1984:19-20).

The artfully composed discourse structure of this ethically challenging pericope is obviously being utilized as a persuasive (rhetorical) device, that is, as a means of shaping and sharpening the intended message so that it will have the greatest possible impact and appeal in relation to a listening audience in particular. It may thus be viewed as a macrotextual equivalent of the "A, and what's more, B, not only A, but B" type of parallel patterning that characterizes biblical poetry (Kugel 1981:13). As the Greek textual display above would indicate, this passage could be classified as an instance of oratorical (poetic) prose, being marked by stylistic features such as rhythmic utterances, alliteration, balanced syntactic patterns, figurative language, conclusion-focused interrogatives, and incorporated direct speech.

In this case the $Y$ panel in each of its internal constituents (B'-E') contrasts with and serves as an effective counterfoil to the corresponding $\mathrm{X}$ unit (B-E). The parallelism of the two panels, $\mathrm{X}$ and $\mathrm{Y}$, reinforces both the duality and polarity of the trial scene: Only two 
clearly defined groups are in the dock, and these are strongly antithetical in terms of character and hence also the judgment that each receives (the only negatives of this passage, eight of them, occur in the Y panel). One, on the right, is publicly vindicated and lauded by the Lord; the other is just as incisively repudiated and condemned. The iterative (a-f // a'-f'), incrementally developed internal bifid arrangement may suggest the certainty of this judicial process as well as the legal precision whereby it is conducted, that is, with regard to one's personal behavior, whether righteous/merciful or the opposite, as it stands in ethical relationship to both Christ and the Christian community (vv. 40, 45). This carefully organized structure may perhaps also be an iconic reflection that depicts the perfectly measured justice of the verdict and the corresponding righteousness of the Judgeas well as the great divide that now distinguishes, and will ultimately separate forever, two fundamentally antithetical ways of life (cf. Ps. 1). The contrastive judicial consequence attached to each of the two character-groups is just as natural as would be the behavior expected of a typical Judean shepherd separating out the more valuable sheep of his flock from the goats at the close of a normal working day (cf. Keener 1993:118).

In any tightly constructed pattern of similarities, one must also consider any prominent variations or differences in terms of their possible rhetorical implications. We note first of all the obvious condensation that appears in the response to the king from the defendants on his left (compare panels D' and D above). It is tempting to view this as a verbal reflection of the very lack of concern for the disadvantaged and needy that such people had just been found guilty of. The Son of Man is recorded as speaking to "the righteous" in his judicial capacity as "king" in verses 34 and 40 (i.e., an inclusio within panel X), whereas he is not referred to in this way in the corresponding verses 41 and 45 . This perhaps suggests that the unrighteous did not recognize or respect the Son's royal authority and thus treated the lesser of his subjects accordingly. The Lord, on the other hand, honors the latter by calling them "my brothers" (v. 40), but significantly the former are not so addressed in the parallel passage (v. 45). The notion of "brotherhood" (universal as well as specifically Christian; cf. Boring 1995:456) certainly distinguishes the ethical attitude and actions of those mentioned in panel $\mathrm{X}$, in sharp contrast to their counterparts in $\mathrm{Y}$, who could not even perceive a "brother," let alone respond to the obvious needs of one (cf. Mt. 7:12). They thought that they could "serve" the absent Lord (v. 44), yet at the same time ignore those on every hand who needed their love (cf. Mt. 22:36-40). Christ's strong condemnation of such "accursed" behavior (v. 41) is timeless in scope, as is the implicit warning that motivates every listener to avoid it (v. 45; cf. Mt.19:16-22).

\section{The rhetoric of Bible translation - on which side should one stand?}

The magnificent structure and moving rhetoric of many a biblical text often turns out to sound quite the opposite in translation. Such is the case with the old Chichewa version (Buku Lopatulika, "Sacred Book," 1923). In terms of verbal style, expression of content, and typographical format, this translation speaks with a very heavy foreign "accent," so much so that in places it is almost unintelligible to ordinary listeners. A great difference is readily (audibly) apparent in the new idiomatic "popular language" edition (Buku Loyera, "Holy Book," 1998), which was prepared by mother-tongue translators. But even though its language is natural and very understandable overall, on a number of occasions, including the passage under consideration, this modern version still fails to reproduce the dynamic style and full rhetorical force of the original.

In this concluding section, I propose several measures that are designed to represent this literary dimension more adequately in Chichewa - that is, is by means of a literary func- 
tional equivalent version ( $L i F E$; cf. Wilt 2002:ch. 6). I am not suggesting that this is the only, let alone the "best," way to prepare a translation; indeed, it is just one option (among many) that may be appropriate for certain audiences and religious settings. When thus "siding" with the vital rhetoric of the original in this way, certain of the microstructural features of the text will inevitably be lost. The benefit in terms of greater communicability in specific situations, however, is a significant factor that may well make it worth the extra effort necessary to produce such a version.

One of the first things to consider in the preparation of a $\mathrm{LiFe}$ version is the issue of potential genre equivalence. Is there TL text-type available that can serve as a close, if not exact, functional equivalent for Christ's last judgment discourse - a dramatic narrative parable that manifests a prominent oratorical style? As it so happens, there is such a flexible literary form in Chichewa, namely, the ndakatulo genre of lyric poetry, which functions well in the reproduction of highly emotive, rhetorically toned passages of the Scriptures (Wendland 1998:185-189). In fact, all of the stylistic features that were listed earlier as being noteworthy with respect to the Matthew's Greek text are very prominent also in the ndakatulo mode of dramatic composition. In addition, the narrative macro-structure itself is quite common in the Chichewa oral narrative tradition (nthano). As Scheub describes this convention from the perspective of Xhosa storytelling technique (1972:134):

$[\mathrm{P}]$ arallel image sets are objectified, portraying positive and negative values within the society through the characters...involved. The details of each of the image sequences are the same.

We have a similar "parallel image set" in our judgment passage, the first positive and the second negative, each of which is reflected off the another to heighten the thematic and moral point of the passage as a whole. This wedding of a dynamic rhetorical style with a familiar narrative structure has the potential for creating a great impression upon any Chewa listening audience.

The medium of hearing must be stressed. It is highly probable that this pericope in Greek has been composed with an oral-aural mode of communication in mind. The entire text is eminently recitable (or chantable) due to all of its verbal recursion, parallel patterning, rhythmic sequences, euphonous combinations of sounds, and an incremental climactic development. The text is therefore very memorable and hence also transmittable as well. Bible translators really need to take this aspect of the discourse into serious consideration as they re-present the text in their language so that it can be as easily and effectively conveyed as in the original. This necessitates in turn a "reader-friendly" display of the discourse on the printed page. It must thus be formatted using the appropriate microand macro-segments-that is, as a sequence of meaningful utterance units combined within narrative "paragraphs." One possible plan would be to follow the Greek text as set out above, using a balanced and terraced sequence of corresponding segments in the vernacular (either with or without the accompanying designative letters along the margin). Such an integrated procedure would surely enhance also the general readability, hearability, and intelligibility of the whole passage as well as its interconnected parts.

A sample translation of Mt. 25:34-36 in the ndakatulo poetic genre and a more natural format is set out below (together with a relatively literal back-translation into English). This particular version has been stylistically reduced somewhat, that is, limited in its overall level of dynamic expression, so that the form of the text does not overshadow or detract in any way from the content that is being communicated. Nevertheless, several graphic ideophones (in boldface) that appeal to the drama of the original setting have been included (to be used only in the first panel, $\mathrm{X}$ ). This experimental rendition represents the ultimate in 
terms of functional (rhetorical) equivalence that is intended to satisfy a specific need for a clearly defined audience. How effective would a translation like this be in such a situation? That answer can be determined only after a sufficiently thorough program of testing has been carried out and the results carefully analyzed.

Tsono Iyeyo ngati Mfumu adauza akudzanja lamanja:

Bwerani kunotu inu odalitsidwa ndi Atate anga. Lowani mu ufumuwu umene adakukonzerani Iyedi, chilengedwere dziko lapansili. Paja Ine ndidaali ndi njala, inu nkundipatsa chakudya. Ndidaali kumva ludzu, inu nkundipatsa chikho pha. Ndadaali mlendo, balamanthu, inu nkundilandira kwanuko.

Ndidaali wamaliseche Ine, inu nkundibveka bwino.

Ndinkadwala mpaka kumanda tswii, inu nkumandizonda ndithu. Ndidaali mange mu ndende, inu nkumadzandichezetsa.
So this one, just like a king, told those at his right hand:

Come right here you people blessed by my Father.

Enter into this kingdom which $\mathrm{He}$ actually prepared for you, since the creation of this very world. You know, I was hungry, right away you gave me some food. I was feeling thirsty, right away you gave me a cup, full up. I was a stranger, arriving all of a sudden, right away you received me into your home.

I was naked, I was, right away you dressed me up well. I was so sick I could have gone straight to the grave, indeed, you kept coming to see how I was.

I was bound up in prison,

You would keep on visiting me.

No matter how dynamic or idiomatic a given translation is, it can never reproduce in the TL the full communicative value of an excellently composed literary source text. A poetic re-creation can perhaps handle most aspects of the textual, stylistic richness, but like any rendering, it too often fails with regard to the implicit level and the great amount of contextual information that is normally presupposed by the original. What can be done to redress this considerable loss of significance? There are a variety of "supplementary helps" available, such as illustrations, cross-references, accompanying notes, section headings, a key-term glossary, concordance, and so forth. But even these will ultimately fall short to a greater or lesser degree due to a lack of adequate situational background knowledge on the part of most receptors, a situation that is usually exacerbated as a result of various intercultural differences and even outright contradictions.

Explanatory footnotes (or auditory asides) offer perhaps the best means of supplying such information, including prominent extralinguistic implications and pertinent applications that arise from the biblical passage at hand (cf. Wendland 2000:152-157). Such a note would be needed, for example, with regard to the concept of a post-death divine "judgment", which is alien to ancient African religious beliefs; rather, a person is judged progressively according to traditional social norms and contemporary mores. The result of this indigenous public verdict is manifested in the after-life only in terms of how one is ultimately regarded and revered as an ancestral spirit. Another culturally-oriented comment of this nature would be needed to explain why sheep were so highly regarded in an ancient near-eastern society; this would include their specific religious symbolism as distinct from goats. Sheep are little known in south-central Africa, except on large, foreign-owned 
commercial farms. Goats, on the other hand, are very common and have a largely negative connotation similar to that of Bible times (Ryken et al, 1998:332), but with rather different contextual associations (in the Scriptures goats are connected with sin in general, in Bantu societies with illicit sexual relations in particular).

So what is the pragmatic "relevance" of rhetoric in relation to discourse structure as far as Bible translation is concerned? It all depends on the type of translation that is being produced and how crucial values such as appropriateness and acceptability will be assessed. When the goal is greater contemporary communicative value, then the dimension of effectiveness will be somewhat more important to achieve than efficiency. In other words, the conceptual "cost" in terms of the relative ease of text processing will be less important than a potential "gain" with regard to cognitive and emotive "contextual effects" (cf. Gutt 1992:21-25), such as relative impact, appeal, artistry, aurality, and memorability. To be sure, Bible translators always want to be on the "right side" as they re-signify the biblical text within the framework of another language and culture. But such a critical judgment can be rightly determined only in relation to a particular audience or reading constituency who need to hear the Word proclaimed to them in a manner that closely resembles that of the original setting of communication. That includes, to the extent humanly possible, also the dramatic content as well as the dynamic style and structure of the Scriptures as they were first written and have subsequently been transmitted to us by a crowd of textual witnesses. 


\section{BIBLIOGRAPHY}

Bailey, JL and Van der Broek, L 1992. Literary forms in the New Testament: A handbook. Louisville: Westminster/John Knox.

Boring, ME 1995. "The gospel of Matthew: Introduction, commentary, and reflections." In The New Interpreter's Bible (Vol. VIII). Nashville: Abingdon Press. 89-505.

Carter, W and Heil, JP 1998. Matthew's parables: Audience-oriented perspectives. Washington: Catholic Biblical Association of America.

Combrink, HJ (Bernard) 1982. "The macrostructure of the gospel of Matthew." Neotestamentica 16:1-20.

1983. "The structure of Matthew's gospel as narrative." Tyndale Bulletin 34:61-90.

Gutt, E-A 1992. Relevance theory: A guide to successful communication in translation. Dallas: Summer Institute of Linguistics.

Keener, CS 1993. The IVP Bible background commentary: New Testament. Downers Grove: InterVarsity Press.

Kennedy, GA 1984. New Testament interpretation through rhetorical criticism. Chapel Hill: University of North Carolina Press.

Kugel, JL 1981. The idea of biblical poetry: Parallelism and its history. New Haven: Yale University Press.

Maartens, PJ 1982. "The structuring principles in Mt 24 and 25 and the interpretation of the text." Neotestamentica 16:88-117 (also Addendum 42-52).

McKnight, Scott 1992. "Matthew, gospel of." In Green, JB and McKnight, S (eds.), Dictionary of Jesus and the gospels. Downers Grove: InterVarsity. 526-541.

Scheub, H 1972. "The art of Nongenile Mazithathu Zenani, A Gcaleka Ntomi Performer. In Dorson, R (ed.), African folklore. Garden City: Doubleday. 115-142.

Wendland, ER 1998. Buku Loyera: An introduction to the new Chichewa Bible translation (Kachere Monograph No. 6). Blantyre: CLAIM.

2000. "Contextualising Bible reading in south-central Africa: The preparation of an annotated edition - with special reference to the gospel of Luke in Chichewa." Neotestamentica 34:1. 143-172.

Wilson, MR 1989. Our father Abraham: Jewish roots of the Christian faith. Grand Rapids: Eerdmans.

Wilt, T (ed.) 2002. Bible Translation: Frames of Reference. Manchester: St. Jerome. 